\title{
Peach mendelian genetics: a short review and new results
}

\author{
R Monet* ${ }^{*}$ A Guye, M Roy, N Dachary \\ Unité de recherches d'arboriculture fruitière et de viticulture, Inra, BP 81, F-33843 Villenave-d'Ornon cedex, France
}

(Received 29 December 1995; accepted 29 April 1996)

\begin{abstract}
Summary - A short review of the knowledge on peach genetics to date is presented in the introduction. Until now, thirty-one phenotypic characters, and ten polymorphic enzymatic systems with mendelian inheritance have been described. Linkages between eight pairs of loci have been established and three genetic maps published. These maps include mainly the location of RAPD and RFLP molecular markers and cannot easily be superimposed. In addition to this review work, results of observations made on a family originated from a test cross between homozygous and heterozygous parents are given for two mendelian phenotypic characters (ie, fruit acidity and fruit shape) and for two isoenzymatic systems (ie, malate dehydrogenase and catalase). A narrow linkage $(5.8 \mathrm{cM}$ ) was found between the locus for fruit acidity $(D / d)$ and that for catalase $(C A T 1-1 / C A T 1-2)$. The other pairs of loci segregate independently, particularly fruit shape (flat/round), and fruit acidity (sweet/acid). This contradicts a previous report of a $35 \mathrm{cM}$ linkage between the loci responsible for these last pairs of characters, assumed from observations made on a small size family.
\end{abstract}

\section{Prunus persica $=$ peach $/$ mendelian genetics $/$ linkage}

Résumé - Génétique mendélienne du pêcher. Bilan et nouveaux résultats. Une étude bibliographique succinte faisant le point sur les connaissances en matière de génétique du pêcher est présentée en introduction. Trente-et-un caractères phénotypiques à hérédité mendélienne ont été décrits, auxquels il faut ajouter dix systèmes enzymatiques polymorphes. Des liaisons ont pu être établies entre huit couples de loci ; trois cartes génétiques de l'espèce ont été publiées, mais elles comportent essentiellement des emplacements de marqueurs moléculaires RAPD ou RFLP et sont difficilement superposables. En supplément à ce travail bibliographique, sont donnés les résultats d'observations réalisées sur une famille issue d'un test cross entre un géniteur homogyzote et un géniteur hétérozygote pour deux caractères phénotypiques mendéliens (acidité du fruit, forme du fruit) et deux systèmes iso-enzymatiques (malate déshydrogénase et catalase). Une liaison étroite $(5,8 \mathrm{cM})$ entre le locus de l'acidité du fruit $(\mathrm{D} / \mathrm{d})$ et celui de la catalase (CAT1-1/CAT1-2) est mise en évidence. Les autres couples se disjoignent indépendamment. Ainsi les couples de caractères allélomorphes forme du fruit (plat/rond), acidité du fruit (doux/acide) ne sont pas liés. Ceci est en contradiction avec la liaison de $35 \mathrm{CM}$ qui avait été pressentie, à partir d'observations faites sur une famille à effectif limité, entre les loci responsables de ce dernier couple de caractères.

Prunus persica $=$ pêcher $/$ génétique mendélienne $/$ liaison génétique

* Correspondence and reprints 


\section{INTRODUCTION}

To introduce the partial results presented here in the context of present knowledge of peach genetics the following review of this knowledge is necessary.

The peach, Prunus persica (L) Batsch, is a diploid species with $2 n=16$ chromosomes. Its relatively small diploid genome is contained in $0.60 \pm 0.03 \mathrm{pg}$ of DNA, ie $5.8 \times 10^{8}$ nucleotide base pairs (Baird et al, 1994). It is a preferential autogamous plant which is quite suitable for genetic studies, except for its long reproductive cycle (three years on average) and for the space taken by each tree.

In this review, we examine successively the polymorphism of 'phenotypic' characters (this term is used in preference to 'morphological' which is too restrictive), of isozymes, and the linkages discovered between these two types of characters. A mention is also made of the three attempts at genetic mapping made with molecular markers in the peach.

\section{Polymorphism of phenotypic characters}

The latest review included twenty-one phenotypic characters of mendelian inheritance (Monet, 1989). The list did not include the 'Wavy leaf' character (symbols $\mathrm{Wa} /$ wa) described by Scott and Cullinan (1942). The 'Slow ripening' character discovered by Brecht et al (1984) was not included, as its heredity was not well established. Finally, we did not include the resistance to Myzus persicae (Massonié et al, 1984) because the first results need to be confirmed (Monet and Massonié, 1994).

Since 1988, seven new characters have been described as follows:

- 'Leaf blotch' (Okie and Reilly, 1989) consists of abnormal foliar spots which are probably the expression of a mutation the inheritance of which has not yet been established.

- 'Pillar' (Scorza et al, 1989) is an upright growth habit tree with narrow angle branches.

- 'Semi-dwarf' peach (SD 22-59) described by Gradziel and Beres (1993) resembles very much the 'A72 dwarf' studied by Monet and Salesses (1975) and might be caused by the same mutation.

- 'Evergreen' is a dominant monogenic character with the symbols Ev/ev (Rodriguez et al, 1994).
- 'Dwarf 3', 'Pollen sterile 2', and 'Wavy leaf 2' discovered and studied by Chaparro et al (1994), with the symbols: $D w 3 / d w 3, P s 2 / p s 2$ and Wa2/wa2 respectively.

The complete list of these characters is given in table I.

\section{Enzymatic polymorphism}

Ten polymorphic enzymatic systems have been described in the peach as follows.

\section{Malate dehydrogenase (EC 1.1.1.37, dimeric enzyme)}

This anodal polymorphism was first underscored by Arulsekar et al (1986) on starch gel electrophoresis. The authors described three zymotypes segregating into a 1:2:1 ratio. Consequently a locus with two alleles seems to be involved, but the zymograms obtained are difficult to interpret. Even though a two-allele locus appears to be the best hypothesis, the slow band is missing in the zymotype corresponding to the slow allele, while it is present in the heterozygous form.

Durham et al (1987) noted that on the zymotype corresponding to the fast allele, two bands (2 and 3) are missing. They nevertheless concluded that the polymorphism is due to the activity of two alleles on the same locus MDH1.

Mowrey et al (1990) have an even more complex interpretation. They obtained six different zymotypes on a starch gel and suggested that such polymorphism comes from a locus $\mathrm{MDH} 1$ with three alleles: MDH1-1, MDH1-2, MDH1-3 (allele 1 being rare, the most common polymorphism would come from alleles 2 and 3 ).

Such interpretation difficulties disappear when acrylamide gel electrophoresis is used. It offers an improved resolution but also requires a purification of the leaf extracts. In acrylamide gels, the slow band corresponding to the allele MDH1-2, which is not visible in starch gels, appears clearly, and so do the bands 2 and 3 of the fast allele zymotype (unpublished data). This demonstrates the existence of a MDH1 locus with two alleles: MDH1-1/MDH1-2.

\section{Diaphorase (EC 1.6.4.3, monomeric enzyme)}

Durham et al (1987) discovered an anodal polymorphism of diaphorase corresponding to one locus DIA1 with two alleles DIA1-1/DIA1-2. 
Table I. Peach mendelian characters.

Characters

Anthocyanin deficiency

Bushy

Albinism

Cotyledon adherent

Compact tree

Sweet fruit (non acid)

Double flower

Dwarf (Bonanza)

Dwarf3

Circular glands

Evergreen

Clingstone (canning)

Nectarine

Red leaf

Dwarf (A72)

Pillar

Weeping tree

Male sterility

Male sterility 2

Red flower

Myzus resistance

Flat peach

Showy flower

Corky triangle

White flower

Wavy leaf

Wavy leaf 2

Yellow flesh

Slow ripening

Leaf blotch

Semidwarf (SD22-59)

\section{$\begin{array}{ll}\text { Dom Rec } & \text { Int } \\ & \text { Dom }\end{array}$}

Symbols Named by

Named by

Yes
Yes

Yes

Yes

Yes

Yes Yes

Yes

Yes

Yes

Yes

Yes

Yes

Yes

Yes

Yes

Yes

Yes

Yes

Yes

Yes

Yes

Yes

Yes

Yes

Yes

Yes

Yes

Yes

Yes

\section{An/an}

Bu1/bu1

Bu2/bu2

$C / c$

$\mathrm{Co} / \mathrm{CO}$

$\mathrm{Ct} / \mathrm{ct}$

$D / d$

$D 1 / d 1$

$D w / d w$

$D w 3 / d w 3$

Yes E/e

Evg/evg

F/f/f1

$G / g$

$G r / g r$

Yes

$N / n$

Pipi

Pl/pl

Ps/ps

Ps2/ps2

$R / r$

$R m 1 / r m 1$

$$
S / s
$$

\section{Sh/sh}

$T / t$

$W / w$

Wa/wa

Wa2/wa2

$Y / y$

$y$

Dom $=$ Dominant $;$ Rec $=$ recessive $;$ Int Dom $=$ intermediate dominance .

\section{Peroxydase (EC 1.11.1.7, monomeric enzyme)}

Durham et al (1987) found a cathodal polymorphism corresponding to one locus with the two alleles: PER1-1 and PER1-2.

\section{Esterase (EC 3.1.1.2, monomeric enzyme)}

Messeguer et al (1987) obtained three zymotypes the inheritance of which has not been established but which correspond, in the simplest interpretation of the zymogram, to the expression of one locus EST1 with two alleles EST1-1, EST1-2.

\section{Isocitrate dehydrogenase (EC 1.1.1.42, mono- meric enzyme)}

Messeguer et al (1987) obtained three zymotypes the mode of inheritance of which has not been established, but which probably correspond to the expression of one locus IDH2 with two alleles. According to the authors, the presence of an even more anodal activity, though not interpretable, justifies the index 2.

However Mowrey et al (1990) did not observe such anodal activity. They consider that the three zymotypes correspond to the activity of one locus IDH1 with two alleles, IDH1-2 and IDH1-3; IDH1- 
1 being reserved for an allele present in some species related to the peach ( $P$ amygdalus). To simplify the symbolism while remaining within the peach species, we will adopt the symbols IDH1-1 and $I D H 1-2$.

\section{Acid phosphatase (EC 3.1.3.2, monomeric enzyme)}

Messeguer et al (1987) obtained zymograms showing two different zymotypes from protein leaf extracts. Though the genetic study of the zymotype inheritance has not been carried out, the most simple interpretation is that involving one locus with two alleles: APS1-1, APS1-2.

\section{Shikimate dehydrogenase (EC 1.1.1.25, monomeric enzyme)}

Mowrey et al (1990) obtained two zymotypes: one with a fast band related to the homozygous genotype, and another with two bands for the heterozygous genotype. After crossing a homozygous with a heterozygous individual, they observed a 1:1 disjunction in the hybrid family. The two alleles were symbolized as $S D H 1-2$ and $S D H 1-3$, the symbol SDH1-1 being reserved for an allele present in species related to the peach and the almond. In order to simplify the symbolism and remain in the peach species, we will adopt, as for isocitrate dehydrogenase, the symbols $S D H 1-1$ and $S D H 1-2$ instead of $S D H 1-2$ and SDH1-3.

\section{$\alpha$-Amylase (EC 3.2.1.1, monomeric enzyme)}

Monet and Gibault (1991) demonstrated that $\alpha$ amylase was polymorphic in the peach, and the three zymotypes present (one slow band, one fast band and two bands) correspond to the expression of one locus with two alleles: AMY1-1 and $A M Y 1-2$.

\section{Catalase (EC1.11.1.6, tetrameric enzyme)}

Werner (1992) observed three zymotypes for the catalase: one slow band, one fast band and five bands. The five band zymotype is explained by the tetrameric nature of the enzyme, as there are five possible combinations of the polypeptides produced by two alleles in heterozygous individuals. The symbols suggested for the two alleles are CAT1-1 and CAT1-2.

\section{Alcohol dehydrogenase (EC 1.1.1.1, dimeric enzyme)}

Monet et al (1994) demonstrated that ADH is polymorphic in the peach and that the zymograms observed represented the activity of three loci, one of which (the one coding for the slowest isozyme) has two alleles. The zymotype interpretation is complicated by the presence of bands issued from the formation of intergenic heterodimers. The two alleles involved in the polymorphism were symbolized as $A D H 3-1$ and ADH3-2.

Table II. Polymorphic isozymes of the peach.

\begin{tabular}{llllll}
\hline Enzymes & $\begin{array}{l}\text { Quaternary } \\
\text { structure }\end{array}$ & $\begin{array}{l}\text { Allele symbols at } \\
\text { the polymorphic locus }\end{array}$ & Discovered by & Date & Comment \\
\hline Malate dehydrogenase & Dimeric & MDH1.1/MDH1.2 & Arulsekar et al & 1986 & \\
Diaphorase & Monomeric & DIA1.1/DIA1.2 & Durham et al & 1987 & \\
$\begin{array}{l}\text { Peroxydase } \\
\text { Esterase }\end{array}$ & Monomeric & PER1.1/PER1.2 & Durham et al & 1987 & Cathodal \\
Isocitrate dehydrogenase & Monomeric & EST1.1/EST1.2 & Messeguer et al & 1987 & \\
Acid phosphatase & Monomeric & IDH1.1/IDH1.2 & Messeguer et al & 1987 & \\
Shikimate dehydrogenase & Monomeric & APS1.1/APS1.2 & Messeguer et al & 1987 & \\
$\alpha$-Amylase & Monomeric & SDH1.1/SDH1.2 & Mowrey et al & 1990 & \\
Catalase & Monomeric & AMY1.1/AMY1.2 & Monet et al & 1991 & \\
Alcohol dehydrogenase & Tetrameric & CAT1.1/CAT1.2 & Werner & 1992 & \\
& Dimeric & ADH3.1/ADH3.2 & Monet et al & 1994 & Interallelic \\
& & & & & heterodimer
\end{tabular}


All the results on the peach enzymatic polymorphism are presented in table II.

\section{Linkages}

Because of the long cycle of the peach sexual reproduction, linkage studies are scarce. The observations gathered were made on families which were not especially created for linkage studies. This is still true for the establishment of genetic maps using molecular markers. Therefore, there has been no systematic study of the different possible associations, although scattered results are now being put together.

All these results, as well as some cases of independent disjunctions observed on other families (partly unpublished due to their secondary interest), are presented in table III.

\section{Genetic mapping and molecular markers}

Three genetic maps of the peach species have been published:

Chaparro et al (1994) built their map using RAPD markers. The map includes 15 groups of linkage homologous two by two (except for the last one which is alone) and covers $396 \mathrm{cM} .83$ RAPD markers, four phenotypic characters (double flower $D I$, pillar tree habit $B r=P i$, purple leaf $G r$ and nectarine $G$ ) and the isoenzymatic locus for catalase (CAT1), are located on the map.

Dirlewanger and Bodo (1994) developed a linkage map consisting of eight linkage groups (corresponding to the eight basic peach chromosomes) and covering $350 \mathrm{cM}$. This map includes 52 RAPD markers and one phenotypic character (weeping habit $W e=P l$ ).

Rajapakse et al (1995) built a map consisting of eight linkage groups and covering $332 \mathrm{cM}$. Forty six RFLP markers, 12 RAPD and three phenotypic markers (double flower $\mathrm{Dl}$, pillar tree habit $\mathrm{Pi}$ and flesh colour $\eta$ are located on the map.

The three maps are difficult to compare, as they are made with different molecular markers and their size was not measured on the same basis (the first one includes homologous linkage groups, the second one does not). The only common feature between the first and third maps, located on the first linkage group, are the two phenotypic characters: double flower $(D I)$ and pillar tree habit $(P i)$.
Rapid progress in establishing the peach genetic map will only be obtained if common molecular markers are adopted, to be used as anchors for the various incomplete maps which will precede the definitive one. The location of phenotypic markers on the final map, remains dependent on the creation of families in which these characters are in disjunction. This is a time-consuming process, but in the meantime, each partial result is interesting and contributes to the progress of the map. Here we present a few results obtained from a cross initially made for creating varieties of flat nectarines (platerines).

\section{MATERIALS AND METHODS}

\section{Plant material}

This study was done on a family originated from a cross between an unnamed flat nectarine S5524 and the round nectarine cv Fantasia. The hybridization made in 1989 produced 468 seeds containing immature embryos which required in vitro culture. Ninetytwo plants were rescued, overwintered in a greenhouse and later planted outdoors in the orchard in 1990. The first fruit yield was obtained in 1992. The two mendelian phenotypic characters which were in disjunction in this family were fruit shape (flat and round) and fruit taste (acid or non acid). The fruit taste is easily identified by simple tasting, or, if in doubt, by measuring titratable acidity of the juice which is always superior to 100 milliequivalents per litre for acid fruits. For these two mendelian characters, the parent S5524 is heterozygous with the genetic symbols $S / s, D / d$ and the parent Fantasia is homozygous recessive: $s / s, d / d$.

\section{Isoenzyme study}

The search for enzyme polymorphism was carried out on leaf protein extracts. Young leaves were harvested in April and May at the tip of actively growing shoots. They were immediately lyophilized and stored at $-80^{\circ} \mathrm{C}$.

The protein extraction method was described by Monet and Gibault (1991), and the electrophoresis technique by Monet et al (1994).

The enzymatic systems found to be in disjunction in the family were the malate dehydrogenase (MDH) and the catalase (CAT). For the latter, a very long migration time (18 h) was necessary, because of the large size of the molecule, to separate the five bands of the heterozygous form. The specific revelation staining methods were those described by Vallejos (1983) for both $\mathrm{MDH}$ and CAT. 
Table III. Couples of independent (I) or linked (L) loci in the peach.

\begin{tabular}{|c|c|c|c|c|c|c|c|c|c|c|c|c|c|c|c|c|c|c|c|c|c|c|c|c|}
\hline CAT1 & & & & & & & & & & & & & & & & & & & & & & & & \\
\hline AMYI & & & & & & & & & & & & & & & & & & & & & & & & \\
\hline MDHI & & & & & & & & & & & & & & & & & & & & & & & & \\
\hline Wavy leaf2 & & & & & & & & & & & & & & & & & & & & & & & & \\
\hline Male sterility2 & & & & & & & & & & & & & & & & & & & & & & & & \\
\hline Dwarf3 & & & & & & & & & & & & & & & & & & & & & 离 & & & \\
\hline Pillar & & & & & & & & & & & & & & & & & & & & & & & & - \\
\hline Weeping tree & & & & & & & & & & & & & & & & & & & & 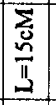 & & - & & \\
\hline Myzus resistance & & & & & & & & & & & & & & & & & - & & & & & 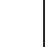 & & \\
\hline Corky triangle & & & & & & & & & & & & & & & & - & & & & & & & & \\
\hline Sweet fruit & & & & & & & & & & & & & & & & & & & & & & & & \\
\hline Anthocyanin def & & & & & & & & & & & & & & & & & & & & & & & & \\
\hline Double flower & & & & & & & & & & & & & & & & & & 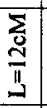 & - & & & & & \\
\hline White flower & & & & & & & & & & & & & & & & & $\begin{array}{l}\sum_{0} \\
\tilde{\pi} \\
\stackrel{1}{1}\end{array}$ & & & 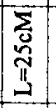 & & - & & - \\
\hline Red flower & & & & & & & & & & & & - & & & & & & & & & & & & \\
\hline Dwarf Bonanza & & & & & & & & & & - & - & & & & & & $\varpi$ & - & & - & & & & \\
\hline Male sterility & & & & & & & & & $m$ & & - & & & $\rightarrow$ & & & 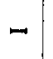 & & & & & - & & - \\
\hline Flat peach & & & & & & & & - & & & & & & 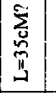 & & & & & & & & & & \\
\hline Red leaf & & & & & & & & & & & - & & & & & & - & - & & & & & & \\
\hline Clingstone & & & & & & & & - & & & & & - & & & & & & & & & & & \\
\hline Nectarine & & & & & & & & - & & - & & - & & & - & & - & - & - & & & & & \\
\hline Eglandular & & & & & - & & & - & & & & & & & & & & & & & & & & \\
\hline Showy flower & & & - & - & - & & & - & & & & & - & - & 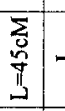 & - & - & & & & & - & 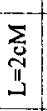 & - \\
\hline Yellow flesh & & - & 1- & $1-$ & - & & - & - & & & & - & & - & - & - & - & - & & & & $\begin{array}{l}\sum_{0} \\
\mathbb{0} \\
\mathbb{U} \\
\end{array}$ & - & $n$ \\
\hline & 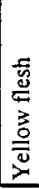 & 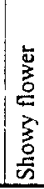 & 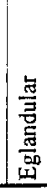 & 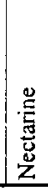 & 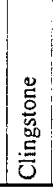 & 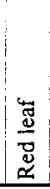 & 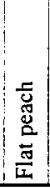 & 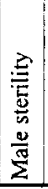 & 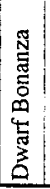 & 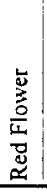 & 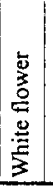 & 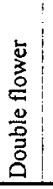 & 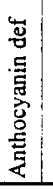 & 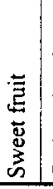 & 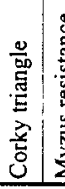 & 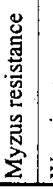 & 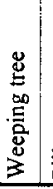 & 产 & $\begin{array}{l}m \\
\vec{t} \\
\vec{z} \\
\vec{z}\end{array}$ & 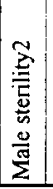 & 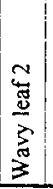 & 졸 & $\sum_{1}$ & F \\
\hline
\end{tabular}


The parent S5524 was heterozygous for the two enzymatic systems with the genetic symbols, $M D H 1$ 1/MDH1-2, CAT1-1/CAT1-2, while Fantasia was homozygous, symbols MDH1-2/MDH1-2, CAT12/CAT1-2.

In fact the cross S5524 x Fantasia represents a test cross for the two phenotypic characters and the two enzymatic systems.

\section{Statistic analysis}

The linkage value is estimated according to the method of maximum likelihood using the formula $(a+d)(1 / p)+(b+c)(1 / 1-p)$, where $p$ is the estimated distance in $\mathrm{cM}$, $a$ and $b$ the frequencies of recombined phenotypes in the test cross family, $b$ and $c$ the frequencies of parental phenotypes (Allard, 1956).

\section{RESULTS}

Five trees died prior to fruit observation and one was an impurity (a peach with fuzzy skin). The genetic study was therefore done on 86 trees.

Table IV presents the frequencies of the two classes of individuals for each character MDH, CAT, fruit shape (round/flat) and fruit taste (acid/non acid).
The observed values must be compared for each character to the theoretical frequency of 43 relative to a $1: 1$ disjunction. In each case they have a high probability of being in agreement with this hypothesis; the family studied is not therefore a biased sample.

Table $V$ shows the results of the statistical analysis carried out to detect linkages for the different associations between any pair of these characters.

In comparison with the theoretical proportions $1: 1: 1: 1$ typical of an independent disjunction (the theoretical value of each case is 21.5), all the observed disjunctions may be regarded as independent except for the CAT1/acid fruit association which does not follow this pattern. The loci for CAT1 and acid fruit are therefore linked with an estimated distance of $5.8 \mathrm{cM}$.

\section{CONCLUSION}

The present knowledge on peach genetics is still small although not negligible compared to that acquired on other woody fruit trees. Obstacles to its rapid progression are of several types:

- rarity of mutant forms; the use of induced gametic mutagenesis should be envisaged in the future to fill this gap;

Table IV. Observed segregations for characters in disjunction ie malate dehydrogenase (MDH), catalase (CAT), fruit acidity and fruit shape.

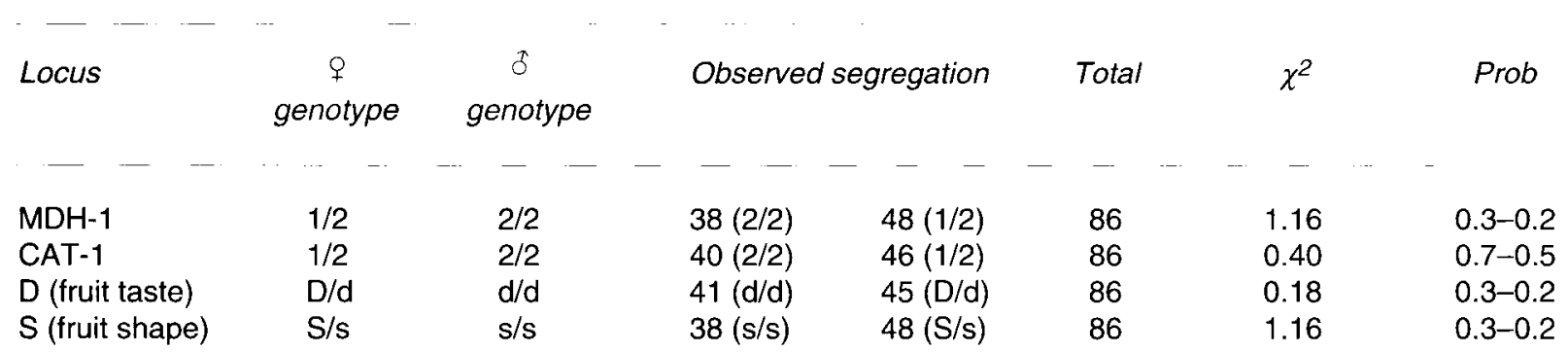

Table V. Detected linkages in the different associations between any two of the four characters.

$\begin{array}{lcll}\text { Joint segregation of: } & \chi^{2} & \text { Probabiity } & \text { Distance in } c M \\ -\quad-\quad- & & - \\ \text { MDH-1/CAT-1 } & 2.37 & 0.50 & - \\ \text { MDH-1/D } & 1.34 & 0.80-0.70 & - \\ \text { MDH-1/S } & 3.01 & 0.50-0.30 & 5.8 \\ \text { CAT-1/D } & 67.7 & <0.001 & - \\ \text { CAT-1/S } & 2.08 & 0.70-0.50 & - \\ \text { D/S } & 2.73 & 0.50-0.30 & \end{array}$


- length of time required to create a family in which new characters are in disjunction;

- lack of coordination in the choice of molecular markers; the establishment of genetic maps should not be done without adopting a minimum number of common markers.

The new results presented in this paper are:

- a relatively narrow linkage between the catalase locus CAT1 and the fruit acidity locus, which means that selection for fruit acidity could be achieved with the help of this marker;

- an independent disjunction between the pairs of loci MDH1-CAT1, MDH1 - fruit acidity, MDH1 - flat fruit shape, CAT1 - flat fruit shape and fruit acidity - flat fruit shape. This last disjunction is in contradiction with the results previously published based on a too small family of 23 plants (Monet et al, 1985). There is probably no linkage between the two characters.

\section{REFERENCES}

Allard RW (1956) Formulas and tables to facilitate the calculation of recombination values in heredity. Hilgardia 24, 235-276

Arulsekar S, Parfitt DE, Beres W, Hansche PE (1986) Genetics of malate dehydrogenase isozymes in the peach. J Hered 77, 49-51

Bailey JS, French AP (1933) The inheritance of certain characters in the peach. Proc Am Soc Hortic Sci 29, 127-130

Baird WV, Estager AS, Wells JK (1994) Estimating nuclear DNA content in peach and related diploid species using laser flow cytometry and DNA hybridization. J Am Soc Hortic Sci 119, 1312-1316

Blake MA (1933) The JH Hale peach as a parent in peach crosses. Proc Am Soc Hortic Sci 29, 131-136

Blake MA (1935) Progress in peach breeding. Proc Am Soc Hortic Sci 35, 49-53

Brecht JK, Kader AA, Ramming DW (1984) Description and postharvest physiology of some slow ripening nectarine genotypes. J Am Soc Hortic Sci 109, 596-600

Chaparro JX, Werner DJ, O'Malley D, Sederoff RR (1994) Targeted mapping and linkage analysis of morphological, isozyme and RAPD markers in peach. Theor App/ Genet 87, 805-815

Connors CH (1920) Peach breeding - A summary of results. Proc Am Soc Hortic Sci 17, 108-115

Connors $\mathrm{CH}$ (1921) Inheritance of foliar glands of the peach. Proc Am Soc Hortic Sci 18, 21-27

Dirlewanger E, Bodo C (1994) Molecular genetic mapping of peach. In: Progress in Temperate Fruit Breeding (H Schmidt, M Kellershals, eds), Kluwer
Academic Publishers, Dordrecht, the Netherlands, 309-311

Durham RE, Moore GA, Sherman WB (1987) Isozyme banding patterns and their usefulness as genetic markers in peach. J Am Soc Hortic Sci 112, 10131018

Gradziel TM, Beres W (1993) Semidwarf growth habit in clingstone peach with desirable tree and fruit quality. Hortscience 28, 1045-1047

Lammerts WE (1945) The breeding of ornamental edible peaches for mild climates. I. Inheritance of tree and flower characters. Am J Bot 32, 53-61

Lesley JW (1940) A genetic study of saucer fruit shape and other characters in the peach. Proc Am Soc Hortic Sci 37, 218-222

Massonié G, Monet R, Bastard Y, Maison P (1984) Heredity in peach of the hypersensitivity reaction to the green peach aphid Myzus persicae. Sulzer. OILB/SROP 7, 69

Mehlenbaker SA, Scorza R (1986) Inheritance of growth habit in progenies of compact Redhaven peach. Hortscience 21, 124-126

Messeguer R, Arùs P, Carrera M (1987) Identification of peach cultivars with pollen isozymes. Scientia Horticulturae 31, 107-117

Monet R (1967) Contribution à l'étude génétique du pêcher. Ann Amélior Plantes 17, 5-11

Monet R (1979) Transmission génétique du caractère "fruit doux" chez le pêcher. Incidence sur la sélection pour la qualité. Eucarpia Symposium Tree Fruit Breeding (INRA ed), Angers, 273-276

Monet R (1989) Peach genetics: past, present and future. Acta Horticulturae 254, 49-57

Monet R, Bastard Y (1977) Mutation induisant une adhérence des cotylédons à la graine chez le pêcher. Ann Amélior Plantes 27, 133-135

Monet R, Bastard Y (1982) Une anomalie du fonctionnement de l'apex chez le pêcher ( $P$ persica $L$ Batsch). agronomie 2, 103-106

Monet R, Gibault B (1991) Polymorphisme de l' $\alpha$ amylase chez le pêcher. Étude génétique. agronomie 11, 353-358

Monet R, Massonié G (1994) Déterminisme génétique de la résistance au puceron vert (Myzus persicae) chez le pêcher. Résultats complémentaires. agronomie 14, 177-182

Monet R, Salesses G (1975) Un nouveau mutant de nanisme chez le pêcher. Ann Amélior Plantes 25, 253-259

Monet R, bastard Y, Gibault B (1985) Étude génétique et amélioration des pêches plates. agronomie 5 , 727-731

Monet R, Bastard Y, Gibault B (1988) Étude génétique du caractère "port pleureur" chez le pêcher. agronomie 8, 127-132

Monet R, Guye A, Roy M (1994) Polymorphisme de l'alcool déshydrogénase chez le pêcher (Prunus persica L Batsch). Étude génétique. agronomie 14, 463-466 
Mowrey BD, Werner DJ, Byrne DH (1990) Inheritance of isocitrate dehydrogenase, malate dehydrogenase and shikimate dehydrogenase in peach and peach $x$ almond hybrids. J Am Soc Hortic Sci 115, 312-319

Okie WR, Reilly CC (1989) Genetic leaf blotch of peach and nectarine. Plant Dis 73, 443

Rajapakse S, Belthoff LE, He G, Estager AE, Scorza R, Verde I, Ballard RE, Baird WV, Callahan A, Monet R, Abbott AG (1995) Genetic linkage mapping in peach using morphological, RFLP and RAPD markers. Theor Appl Genet 90, 503-510

Rodriguez AJ, Sherman WB, Scorza R, Wisniewski M, Okie WR (1994) 'Evergreen' peach, its inheritance and dormant behavior. J Am Soc Hortic Sci 119, 789-792
Scorza R, Lightner GW, Liverani A (1989) The pillar peach tree and growth habit analysis of compact $\mathrm{x}$ pillar progeny. J Am Soc Hortic Sci 114, 991-995

Scott DH, Cullinan FP (1942) The inheritance of wavyleaf character in the peach. $J$ Hered 33, 293-295

Scott DH, Weinberger JH (1944) Inheritance of pollen sterility in some peach varieties. Proc Amer Soc Hort Sci 9, 187-188

Vallejos CE (1983) Enzyme activity staining. In: Isozymes in Plant Genetics and Breeding, part $A$ (SD Tanksley, TJ Orton, eds), Elsevier, Amsterdam, 469-516

Werner DJ (1992) Catalase polymorphism and inheritance in peach. Hortscience $27,41-43$ 